\title{
WHY NOT RESTATE THE ENGLISH LAW OF OWNERSHIP OF LAND
}

\author{
James Edwaid Hogg \\ Sydney, Australia \\ PREFATORY NOTE
}

The following article was written in London, and from the English point of view, before the introduction into Parliament of the Law of Property Bill. That Bill is the present result of the reform movement to which reference is made at the end of the article. The Bill was read a second time in the House of Lords on February 26 th, I920, but its fate is still uncertain, and the most meagre description of it-to be intelligible-would occupy many times the space of this article. A few words, however, may be of interest to American lawyers in explanation of the relation of the Law of Property Bill to the existing theory of English law on the subject of land ownership, and that explanation will show how very far short of the ideal reform here advocated the Bill falls. A succinct account of the Bill is given by Mr. Arthur Underhill in the Law Quarterly Review for April, I920, ${ }^{1}$ and this account will convey to the reader a fair idea of the complexity of the measure-perhaps one of the longest bills ever presented to a legislative body. The Bill itself must, however, be seen and perused to be appreciated! For the benefit of American readers attention may be called to a parliamentary paper on which the Bill is actually founded. ${ }^{2}$ This report and Mr. Underhill's article will give as much information as can well be imparted by anything short of a study of the actual text of the Bill itself.

For the present purpose Lord Birkenhead's Law of Property Bill may be described as the result of rolling together three subsidiary reform movements that have been quickly gathering way in Lincoln's Inn, without attracting much public attention, during the last few years. A number of conveyancers, feeling the need of practical reform by way of extensive amendment of such statutes as the Conveyancing Acts, Settled Land Acts, etc., have for some time been engaged in putting their views into definite shape. Mr. Arthur Underhill, apart from these proposed amendments, attracted some notice recently by publishing a.pamphlet entitled The Line of Least Resistance, in which

\footnotetext{
'Lord Birkenhead's Law of Property Bill (I920) 37 LAW QUaR. REv. I0\%. [See also articles by Charles P. Sanger (1920) 20 CoL. L. REv. 652, and Prof. Manley O. Hudson (I92I) 34 Harv. L. REv. 34I.-Ed.]

${ }^{2}$ Fourth Report of the Acquisition and Valuation of Land Committee on the Transfer of Land in England and Wales (London, Igig) Cd. 424.
} 
he advocated the assimilation of the fee simple to an estate for years for certain purposes, giving to freehold land many of the incidents of leasehold, but pointedly refraining from any advocacy of a change in the theory of ownership by dependent tenure. The third of the subsidiary movements was due to a general notion widely disseminated, but not easy to seize in any tangible expression of opinion, that the transfer of land was much more cumbersome and expensive than it need be, and that more could be done than was being done in the direction of registration of title to land under the Land Transfer Acts of I875 and I897. The Report of I9I9 has rolled these three movements together, and Lord Birkenhead's Bill is the result.

The link between the new Bill and the following article is to be found in the proposals embodied originally in Mr. Underhill's pamphlet (which is printed in extenso in the Report of 1919) for assimilating the law of freehold land to that of leasehold. Like the Bill itself, though not for the same reasons, Mr. Underhill's pamphlet must be read in order to be appreciated, but one or two sentences will illustrate its tendency sufficiently for the present purpose.

"What, then, is the remedy for this state of things? Some say, Sweep away the whole of the rubbish and commence de novo. That is a counsel of perfection, but quite impracticable. . . . The third plan, which I venture to think is the line of least resistance, is . . . to enact (in effect) that henceforth all land now held as freehold or copyhold shall have precisely the same legal incidents as if were leasehold land holden for a term of say 100,000 years at a peppercorn rent."

This is the proposed reform in a nutshell. Dependent tenure is not to be abrogated expressly, but freehold land is to have the incidents of leasehold-an extreme instance of the reform by "specific enactment" advocated by the Real Property Commissioners in 1832, but hitherto found lamentably insufficient to simplify the law. It is for the purpose of advocating reform in the principle and theory of. ownership of land, and not mere hand to mouth amendment of our land law, that the following article was written-before, I must repeat, the appearance of the Law of Property Bill.

Some idea of the general scope and purpose of the new Bill may be gained by quoting, from the Memorandum prefixed to it, the two opening paragraphs. These are as follows:

"This Bill will effect a greater simplification in the practice of conveyancing, without, however, destroying the power to settle land, than any measure hitherto proposed. The general proposals are discussed in a pamphlet entitled 'The Iine of Least Resistance' by $\mathrm{Mr}$. Arthur Underhill. The main object is to assimilate the law of real and personal estate. The general principle is enacted in clause one, which puts freehold and customary land on the same footing as leaseholds and repeals the Statite of Uses. This principle is worked out in different parts of the Bill. By itself the general principle would not do much to assist a purchaser, for, to obtain a good title, he not only has 
to acquire the fee simple or the term of years which he buys, but has to see that the equities and charges affecting the land are bound.

"Hence the Bill places all interests in land, except legal estates in fee simple or for a term of years absolute, behind a curtain consisting of either a trust for sale or a settlement, and frees a purchaser in good faith from any obligation to look behind the curtain. By this method, with the aid of the provisions relating to mortgages and the legal estate, the reforms sought in Lord Haldane's Bill of I9I5 are, with insignificant exceptions, carried out, without the complications incidental to that scheme, without inventing any new nomenclature, and without setting up a register of cautions and inhibitions."

WHY NOT RESTATE THE LAW OF OWNERSHIP OF LAND?

Two diametrically opposite opinions have been expressed concerning the English law of real property. In the preface to Theobald's Law of Land ${ }^{3}$ it is said, with reference both to the law of land and English law in general:

"To those who take the trouble to distil it out from the mass of cases in which it is held in solution, it presents as glorious a work of fine intelligence as that of any other country."

In Igo6 the late Arthur Cohen said, in presiding at a lecture on RomanDutch law :

"In truth, no sane person who could help it would now devote any time to mastering the English law of real property."

These extreme statements may perhaps be reconciled if it is borne in mind that the former refers to the substance of the law, the latter to its form. The condemnation of the English law of land is justified by the fact that an outworn theory of ownership continues to be formally recognized, and praise of the same law is justified because in spite of a useless and hampering theory rights of ownership are protected by a system of law which is administered with regard to substantial justice. What is wanted is that the theory of the law of ownership should be made to accord with the practical circumstances of possession and use of land. The technical basis of the law of ownership should be restated in terms of actual fact.

The Real Property Commissioners in 1832 thought a sufficient case had not been made out for abolishing the principle of tenure and making all lands allodial. ${ }^{5}$ They were for doing away with all tenures but free and common socage; this tenure, however, they considered, had "all the advantages of allodial ownership" on the ground that "the dominium utile vested in the tenant comprises the sole and undi"vided interest in the soil," escheat being "the only material incident of "the tenure beneficial to the lord." The "few inconveniences arising

(I902) vi.

- (Ig07) 7 Jour: Comp. LEa 356.

See Third Report, at pp. 3-7. 
"from the principle of tenure" which still remained could, the Commission thought, "be remedied by specific enactment." But times have changed since this Report was made. This very remedy "by specific "enactment" has proved the bane of land law reform, and has in fact prevented the realization of a reform going to the root of the evil-the abrogation of a useless theory out of harmony with actual fact. Moreover, a positive restatement is required, as well as abrogation of the principle of dependent tenure.

With respect to the occasional need for a new legal conception of existing rights and duties I should like to refer to an article of my own written some years ago, Legal Conceptions From a Practical Point of View. ${ }^{6}$ The new doctrine of Relativity in physical science shows how scientific conceptions have to be changed to accord with ascertained facts, and in the same way in the sphere of jurisprudence it is time to bring the theory of land ownership more into line with acknowledged practical truths. The theory or principle of dependent tenure has had definite consequences in shaping our law of land, and we ought now to state the law in terms of those results, and not insist on trying to make the original theory fit into a frame of fact which has plainly grown too large for. it. The English fee simple has by this time come to be an ownership as real and as well entitled to be so called as the ownership of chattels. Reference may perhaps be permitted to another article of my own, The Effect of Tenure on Real Property Law, in which it is pointed out that the fee simple estate does confer proprietorship of the soil as fully as under other systems of law proprietorship is conferred by a formal dominium.

The effect of dependent tenure has been to create two different species of ownership of land, viz., time-ownership and space-ownership. Under the civil law these would be represented by a dominium and servitudes. In English law the tenant for life, the leaseholders or tenant for years, and the tenant in fee simple all own their land and have not merely a burden or servitude on another's land. When a distinction between one such owner and another has to be drawn, such terms as "limited "owner" and "full owner" may be employed.' With regard to spaceownership, the English "horizontal hereditaments" is unknown to the civil law. Though not so obviously the result of the principle of tenure, English land can be divided horizontally as well as vertically and each separate stratum may be the subject of separate ownership for life, for years, in fee simple, etc. These two species of ownership have regard to the quantum or amount of property owned, measured by time and space respectively.

With regard to what may be called the quality of the ownership, or the kind of rights of which it is constituted, there are five of such

\footnotetext{
- (Ig06) 22 Law Quar. REv. 172.
}

' (I909) 25 LAW QUaR. REv. I78. 
qualities or kinds of rights of ownership. These all constitute legal ownership, in the sense that they are recognized by law, but the use of the word "legal" is beset with difficulties, being in one sense sharply distinguished from "equitable." 8 The five kinds of ownership now referred to are: (I) common-law or "legal" ownership, in the narrow sense; (2) equitable ownership; (3) ownership by virtue of a power or powers; (4) ownership conferred by the provisions of some statute, independently of any of those preceding kinds of ownership; (5) registered ownership under a system of registration of title.

Now to whatever extent the doctrine of seisin, the last outpost of the principle of tenure, still survives with regard to the first head in the above classification-common-law ownership-neither tenure nor its resultant seisin are anything but the purest fictions as applied to the other four heads or kinds of ownership. Such expressions as "equitable "seisin" are simply metaphors, and are not to be taken as implying that the doctrine of seisin, etc., has been introduced into equitable ownership. Even with respect to common-law ownership, seisin and dependent tenure are excluded from one division-leasehold land. The relation of landlord and tenant, lessor and lessee, reversioner and termorwhichever expression may be used-has nothing to do with the doctrine of common-law or dependent tenure, but is ultimately based on the principle of contract-not tenure.

The common-law ownership of freehold land (to which may. be added copyhold and customary land) being the only kind of ownership which now has anything to do with dependent tenure and seisin, is there any common principle that can serve as a basis for ownership of other kinds-leasehold, equitable, under powers, statutory, registered? While each of these differs from all the others of the five in some respects, it seems possible to enunciate a theory of ownership which shall apply to all, and it is this:

Land ownership of these five kinds is constituted by possession coupled with the right to possession, the right'being evidenced by documents consisting either of (I) a grant or disposition from a former owner, or (2) the provisions of a statute, or (3) an official register.

It is of course in the case of leasehold and equitable awnership and ownership under a power or powers that the documentary evidence consists of a grant or disposition from a former owner.

Besides this distinction between leasehold, etc., on the one hand and statutory and registered ownership on the other, with regard to evidence of the right to possession, there is another distinction of great importance between leasehold and equitable ownership on the one hand and the other three kinds-under powers, statutory, registered-on the

'In Warren v. Murray [1894] 2 Q. B. 648, 65I, Lord Esher referred to "the actual legal rights of the parties, meaning thereby their equitable as well as their common law rights." 
other. In the case of leasehold and equitable ownership the owner's rights are considered to exist by virtue of his having an "estate" in the land analogous to the estate of common-law ownership, which has given rise to what seems better expressed by the notion of time-ownership. In the case of ownership under a power or powers the owner has no "estate," but has had conferred on him by the disposition of a former owner merely a "power" to deal with the land in any way he pleases. In the case of statutory and registered ownership, although the notion of an estate in the land being, vested in the owner is not so explicitly excluded as in the case of a power of ownership, yet it is emphatically the land itself as a subject of property, and not a mere "estate" in it, that is the primary object of any vesting dispositions expressly or impliedly made by the relevant statute or register. With respect to registered ownership this may require some modification, but on the whole registered approximates more closely to statutory ownership than to ownership by virtue of estates; it is perhaps half way between ownership by estate and ownership of power.

It is perhaps not very generally recognized that, even in English law, what is substantially ownership of land can exist without the owner having an actual "estate" in the land in the technical sense. In the case of a general power-a power of ownership-the distinction between having such a power and having an estate in fee simple is merely technical. "You can create the same estates and limitations "under a general power of appointment as you can where you have the "fee," and it was said long ago by Maine that "the later Roman "jurisprudence, like our oum, looked upon uncontrolled power over "property as equivalent to ownership."11 The notion of ownership of the land without an estate in it comes out still more strongly in the case of statutory ownership-where ownership is actually conferred by the provisions of some statute. One illustration is the vesting of streets, etc., in public authorities, ${ }^{12}$ who thus become statutory owners. Another is the case of "absolute title" acquired by a "possessory owner" under limitation statutes. ${ }^{13}$ Such an owner is constantly referred to in réported cases as a "statutory owner," and it has been definitely laid down by the Court of Appeal that a person who thus "holds by a title

- The registered owner under the Land Transfer Acts, 1875 and $x 897$ has been held to have "a statutory power to transfer the property by a registered disposition" which "takes effect by virtue of an overriding power, and not by virtue of any estate" in him: Capital \& Counties Bank v. Rhodes [1903] I Ch. 631, 635. But this may not be completely true of all systems of registration of title.

${ }^{10}$ Rous $v$. Jackson (1885) L. R. 29 Ch. Div. 521, 526, where Butler's note on Co. Lit. $272 \mathrm{a}$ is referred to.

"I Ancient Law (Pollock's ed. 1906) 25I.

${ }_{13}^{18}$ For instance, sec. 149 of the Public Health Act, 1875.

${ }^{18}$ The quoted expressions occur in the Privy Council's judgment delivered by

Lord MacNaghten in Perry v. Clissold [1907] A. C. 73, 79. 
"under the statute" does not so hold by any statutory transfer of "the "estate" of the dispossessed owner. ${ }^{14}$ The registered owner also may have ownership without any "estate" in the technical sense being referred to.

If, as is here contended is the case, common-law ownership of freehold land, though still capable of being described in terms of dependent tenure, is also rightly called ownership in every proper sense of the word, and if the other kinds of ownership above referred toleasehold, equitable, under powers, statutory, registered-are rightly called ownership, independently altogether of the principle of dependent tenure: if this is so, why not adopt a simpler nomenclature and a simpler theory by definitely calling each of these six classes of rights in land "ownership," without allowing the express or implied "quasi-" to creep in from the region of fictions and bygone jurisprudence?

It is not suggested that these different kinds of ownership should be amalgamated, or that rights and liabilities under them should be altered, but only that they should be formally recognized as "ownership" in theory as well as practice. Possibly they will not all continue to flourish equally when thus placed on the same level juridically. For instance, common-law ownership may tend to become obsolete, and registered ownership may become more general. In time commonlaw ownership of freehold land may come, or might even now be expressly made, to rest on the same theoretical basis as other forms of ownership, and the general theory could then be stated thus:

Ownership of land is constituted by possession coupled with the right to possession, this right being evidenced by documents consisting of (I) a grant or disposition from a former owner, or (2) the provisions of a statute, or (3) an official register.

Whatever the form of 'ownership, it would in every case be (in point of duration) either in perpetuity or for a defined time, and (in point of area) either a centro ad coelum or in respect of a defined space.

If the latest attempt at remedying the inconveniences of our land law "by specific enactment" should, as the result of the labors of the Committee on Land Transfer, issue in a well-devised scheme of detailed reform, it would then be easier to place the theory of land on a new footing by such a restatement as is here suggested.

"Tichborne v. Weir (1892, C. A.) 67 L. T. 735. 